\title{
Pengaruh Manajemen Persediaan dan Manajemen Piutang Terhadap Modal Kerja Perusahaan (Studi Kasus Pada Perusahaan Manufaktur Sektor Industri Barang Konsumsi yang Terdaftar di BEI)
}

\author{
Siti Wily Azizah \\ Program Studi Pendidikan Akuntansi, FPEB, Universitas Pendidikan Indonesia, Bandung, Indonesia
}

\begin{abstract}
This study aims to determine the effect of inventory management with indicators of inventory turnover (ITO) and accounts receivable management with indicators of accounts receivable turnover (RTO) on the company's working capital. The object of this study is a consumer goods manufacturing sector listed on the Indonesian Stock Exchange for 5 years with a total of 100 observation data. The research method used is descriptive and verification method. The data collection techniques used are the study of documentation on the balance sheet and income statement of manufacturing companies in the consumer goods industry sector listed on the IDX. The statistical analysis used in this study is multiple linear regression analysis techniques for panel data with the help of Eviews 8 application. Based on the test results obtained that simultaneously inventory management and accounts receivable management negatively affect the company's working capital. Partially, inventory management has a significant negative effect on the company's working capital, while accounts receivable management has a significant negative effect on the company's working capital.

Keywords. inventory management; management of accounts receivable; company working capital; inventory turnover; receivable turnover
\end{abstract}

\begin{abstract}
Abstrak
Penelitian ini bertujuan untuk mengetahui pengaruh manajemen persediaan dengan indikator perputaran persediaan (ITO) dan manajemen piutang dengan indikator perputaran piutang $(R T O)$ terhadap modal kerja perusahaan. Objek pada penelitian ini adalah perusahaan manufaktur sektor industri barang konsumsi yang terdaftar di BEI selama 5 tahun dengan total 100 data observasi. Metode penelitian yang digunakan adalah metode deskriptif dan verifikatif. Adapun teknik pengumpulan data yang digunakan adalah studi dokumentasi terhadap laporan neraca dan laporan laba rugi perusahaan manufaktur sektor industri barang konsumsi yang terdaftar di BEI. Analisis statistik yang digunakan dalam penelitian ini adalah teknik analisis regresi linier berganda untuk data panel dengan bantuan aplikasi EViews 8. Berdasarkan pengujian diperoleh hasil bahwa secara simultan manajemen persediaan dan manajemen piutang berpengaruh negatif terhadap modal kerja perusahaan. Secara parsial, manajemen persediaan berpengaruh negatif signifikan terhadap modal kerja perusahaan, sedangkan manajemen piutang berpengaruh negatif tidak signifikan terhadap modal kerja perusahaan.
\end{abstract}

Kata kunci. manajemen persediaan; manajemen piutang; modal kerja perusahaan; perputaran persediaan; perputaran piutang.

Corresponding author. Email. sitiwilyaziizah@gmail.com

How to cite this article. Azizah, S. W. (2017). Pengaruh Manajemen Persediaan dan Manajemen Piutang Terhadap Modal Kerja Perusahaan (Studi Kasus Pada Perusahaan Manufaktur Sektor Industri Barang Konsumsi yang Terdaftar di BEI). Jurnal Pendidikan Akuntansi Dan Keuangan, 5(2), 61-70. Retrieved from http://ejournal.upi.edu/index.php/JPAK/article/view/15404

History of article. Received: Februari 2017, Revision: Mei 2017, Published: Juli 2017

\section{Pendahuluan}

Setiap perusahaan memerlukan modal kerja untuk menunjang kegiatan operasional sehariharinya. Jika aset lancar melebihi hutang lancar, perusahaan mempunyai modal kerja bersih positif, sedangkan jika aset lancar lebih kecil dari hutang lancar, perusahaan mempunyai modal kerja bersih negatif. Kondisi modal kerja suatu perusahaan dapat dilihat dari kebutuhan modal kerjanya seperti pada tabel di bawah

Tabel 1 Modal Kerja dan Kebutuhan Modal Kerja Perusahaan Manufaktur yang Terdaftar di BEI Tahun 2014 


\begin{tabular}{lllll}
\hline No & $\begin{array}{c}\text { Kode } \\
\text { Perusahaan }\end{array}$ & $\begin{array}{c}\text { Kebutuhan } \\
\text { Modal Kerja }\end{array}$ & $\begin{array}{c}\text { Modal } \\
\text { Kerja }\end{array}$ & $\begin{array}{c}\text { Kekurangan / } \\
\text { Kelebihan } \\
\text { Modal Kerja }\end{array}$ \\
\hline 1 & MLBI & 150.603 & $(772.307)$ & $(922.910)$ \\
2 & SKLT & 76.331 & 25.994 & $(50.337)$ \\
3 & STTP & 23.272 & 260.799 & 237.527 \\
4 & HMSP & 19.978 .183 & 7.177 .284 & $(12.800 .899)$ \\
\hline 5 & RMBA & 3.494 .202 & 10.475 & $(3.483 .727)$ \\
6 & MBTO & 381.852 & 329.938 & $(51.914)$ \\
7 & TCID & 895.730 & 387.963 & $(507.766)$ \\
8 & UNVR & 1.131 .799 & $(2.527 .662)$ & $(3.659 .461)$ \\
9 & LMPI & 110.107 & 88.173 & $(21.934)$ \\
\hline
\end{tabular}

Sumber: Laporan Keuangan Perusahaan Tercatat di BEI (data diolah)

Dilihat dari tabel di atas hanya satu perusahaan yang modal kerja bersihnya melebihi kebutuhan, yaitu PT Siantar Top Tbk. Kelebihan modal kerja ini memperlihatkan bahwa perusahaan dapat menjamin likuiditasnya. Namun, modal kerja yang terlalu jauh melebihi kebutuhannya juga tidak baik. Menurut Andari (2009:31) "Bilamana modal kerja terlalu besar dan dana yang tertanam dalam modal kerja melebihi kebutuhan, maka akan terjadi idle fund." Idle fund ini akan mengurangi kemampuan perusahaan dalam memperoleh laba.

Kekurangan modal kerja juga tidak baik, karena akan menghambat operasional perusahaan. Bila modal kerja terlalu kecil atau kurang, maka perusahaan akan mengalami kesulitan memenuhi kewajiban jangka pendeknya. Seperti yang terjadi pada delapan perusahaan pada tabel di atas yang modal kerjanya jauh lebih kecil daripada kebutuhan modal kerja perusahaan. Bahkan dua di antaranya yaitu PT Multi Bintang Indonesia Tbk. dan PT Unilever Indonesia Tbk. mempunyai modal kerja bersih negatif.

Mengelola modal kerja juga berarti mengelola unsur-unsur di dalamnya, termasuk persediaan dan piutang. Kedua unsur aset lancar tersebut merupakan bagian terpenting dari aset lancar perusahaan.

Penelitian ini dilakukan untuk mengetahui bagaimana pengaruh yang ditimbulkan dari manajemen persediaan dan manajemen piutang, baik secara parsial maupun simultan terhadap modal kerja perusahaan manufaktur sektor industri barang konsumsi yang terdaftar di BEI pada tahun 2014.

\section{Landasan Teori}

\section{Modal Kerja}

Menurut Irawati (2006:89) "Modal kerja merupakan investasi perusahaan dalam bentuk aset lancar atau current assets." Sedangkan menurut Kasmir (2008:250) "Modal kerja merupakan modal yang digunakan untuk melakukan kegiatan operasi perusahaan." Sehingga dapat disimpulkan bahwa modal kerja adalah suatu bentuk investasi pada aset lancar yang diperlukan oleh perusahaan untuk memenuhi kebutuhan operasionalnya.

\section{Net Working Capital}

Menurut Sudana (2011:189) "Modal kerja bersih atau net working capital adalah selisih antara aset lancar dan hutang lancar." Konsep modal kerja bersih tidak hanya melihat modal kerja dari sudut pandang investasi, tetapi juga dari sudut pandang pendanaan. Bagian aset lancar untuk membayar utang tidak termasuk dalam modal kerja bersih perusahaan.

\section{Manajemen Persediaan}

Margaretha (2011:38) mengungkapkan bahwa "Persediaan adalah sejumlah bahan/barang yang disediakan oleh perusahaan, baik berupa barang jadi, bahan mentah, maupun barang dalam proses yang disediakan untuk menjaga kelancaran operasi perusahaan guna memenuhi permintaan konsumen setiap saat."

Manajemen persediaan adalah kegiatan untuk menentukan jumlah dan komposisi persediaan sehingga perusahaan dapat melindungi kelancaran produksi dan penjualan serta kebutuhan pembelanjaan perusahaan dengan efektif dan efisien, termasuk mengatur dan mengawasi pelaksanaan pengadaan bahanbahan yang diperlukan dengan biaya serendahrendahnya.

\section{Perputaran Persediaan (ITO)}

Tingkat efisiensi persediaan dapat dilihat dari perputaran persediaannya. Menurut Syamsuddin (2007:47) "Likuiditas atau aktivitas dari persediaan di dalam perusahaan diukur dengan tingkat perputaran dari persediaan tersebut." Semakin tinggi turnover yang diperoleh, semakin efisien perusahaan melaksanakan operasionalnya.

Dalam menentukan baik tidaknya perputaran persediaan, dapat dibandingkan dengan rata-rata industrinya. Menurut Brigham \& Houston (2011:136) "Rata-rata industri 
untuk rasio perputaran persediaan adalah sebesar 10,9 kali." Artinya manajemen persediaan yang baik akan mengganti persediaannya sebanyak 10,9 kali per tahun, atau rata-rata persediaan disimpan dalam gudang sekitar 34 hari.

\section{Manajemen Piutang}

Menurut Margaretha (2011:52) "Piutang adalah aset atau kekayaan yang timbul sebagai akibat dari dilaksanakannya penjualan secara kredit." Piutang dari penjualan kredit dapat menimbukan biaya bagi perusahaan. Oleh karena itu, manajemen piutang merupakan pengelolaan piutang agar kebijakan kredit mencapai optimal, yaitu tercapainya keseimbangan antara biaya yang diakibatkan oleh kebijakan kredit dengan manfaat yang diperoleh dari kebijakan tersebut.

\section{Perputaran Piutang (RTO)}

Piutang sebagai salah satu elemen modal kerja selalu dalam keadaaan berputar. Menurut Harjito \& Martono (2014:101) "Perputaran piutang (receivable turnover) merupakan periode terikatnya piutang sejak terjadinya piutang tersebut sampai piutang tersebut dapat ditagih dalam bentuk uang kas dan dibelikan kembali menjadi persediaan dan dijual secara kredit menjadi piutang kembali." Tingkat perputaran piutang dapat dicari dengan membagi jumlah penjualan kredit bersih (net credit sales) per tahun dengan rata-rata piutang (average receivables).

Sutrisno (2012:57) mengungkapkan bahwa "Semakin tinggi tingkat perputaran piutang semakin efisien piutang tersebut atau semakin cepat piutang dibayar maka semakin efisien piutang tersebut." Dalam menentukan baik tidaknya perputaran piutang suatu perusahaan, dapat dibandingkan dengan rata-rata industrinya. Menurut Brigham \& Houston (2011:137) "Rata-rata industri untuk periode pengumpulan piutang adalah 36 hari." Untuk mengetahui rata-rata industri untuk perputaran piutang, jumlah hari dalam setahun dibagi periode pengumpulan piutang $=365 / 36=10,1$ kali. Artinya, manajemen piutang yang baik mempunyai perputaran piutang sebesar 10,1 kali per tahun.

\section{Metode Penelitian}

Metode yang digunakan adalah metode deskriptif dan verifikatif. Metode deskriptif dan verifikatif adalah penelitian yang menggambarkan fakta-fakta, sifat-sifat dan hubungan antar variabel dalam upaya membuktikan kebenaran teori yang telah ada atau hipotesis yang telah dibuat.

Variabel bebasnya adalah manajemen persediaan yang diproksikan oleh perputaran persediaan dan manajemen piutang yang diproksikan oleh perputaran piutang. Variabel terikatnya adalah modal kerja perusahaan. Di mana modal kerja perusahaan di sini adalah modal kerja dalam konsep kualitatif yaitu modal kerja bersih.

Populasinya adalah seluruh perusahaan manufaktur sektor industri barang konsumsi yang terdaftar di BEI yaitu sebanyak 37 perusahaan. Sementara sampelnya adalah:

Tabel 2. Perusahaan Sampel

\begin{tabular}{lll}
\hline No & \multicolumn{1}{c}{ Nama Perusahaan } & Kode \\
\hline 1 & PT Delta Djakarta Tbk. & DLTA \\
2 & PT Indofood CBP Sukses Makmur & \\
& Tbk. & ICBP \\
3 & PT Mayora Indah Tbk. & MYOR \\
4 & PT Sekar Laut Tbk. & SKLT \\
5 & PT Siantar Top Tbk. & STTP \\
6 & PT Ultrajaya Milk Industry Tbk. & ULTJ \\
7 & PT Darya-Varia Laboratoria Tbk. & DVLA \\
8 & PT Indofarma Tbk. & INAF \\
9 & PT Kimia Farma Tbk. & KAEF \\
10 & PT Kalbe Farma Tbk. & KLBF \\
11 & PT Merck Tbk. & MERK \\
12 & PT Pyridam Farma Tbk. & PYFA \\
13 & PT Merck Sharp Dohme Pharma & SCPI \\
& Tbk. & \\
14 & PT Tempo Scan Pacific Tbk. & TSCP \\
15 & PT Martina Berto Tbk. & MBTO \\
16 & PT Mustika Ratu Tbk. & MRAT \\
17 & PT Mandom Indonesia Tbk. & TCID \\
18 & PT Kedawung Setia Industrial Tbk. & KDSI \\
19 & PT Kedaung Indah Can Tbk. & KICI \\
20 & PT Langgeng Makmur Industri & \\
& Tbk. & LMPI \\
\hline Sum & & \\
\hline
\end{tabular}

Sumber: http://www.sahamok.com, diunduh 2 Oktober 2015

Penelitian akan dilakukan terhadap laporan keuangan 20 sampel perusahaan selama periode 2010-2014 yaitu 5 tahun. Maka data 
observasi pada penelitian ini berjumlah 100 data.

\section{Uji Asumsi Klasik}

Sebelum melakukan uji regresi, dilakukan terlebih dahulu uji asumsi klasik. Untuk uji regresi linier berganda menurut Yamin (2011:29) asumsi yang digunakan adalah sebagai berikut:

- $\varepsilon_{i} \sim \mathrm{N}(0, \sigma)$, error mengikuti fungsi distribusi normal.

- Var $\left(\varepsilon_{i}\right)=\sigma^{2}$, varians error bersifat homoskedastisitas (tidak ada masalah dengan heteroskedastisitas).

- Cov. $\left(\varepsilon_{i}, \varepsilon_{j}\right)=0$, variabel di antara pengamatan error bersifat independen (tidak ada masalah otokorelasi).

- Tidak ada masalah multikolinieritas (terdapat korelasi tinggi di antara variabel independen).

\section{Uji Regresi Data Panel}

Data panel merupakan gabungan antara data cross-section (silang) dengan data time-series (deret waktu). Analisis regresi dengan data panel dapat dilakukan dengan beberapa metode. Menurut Yamin (2011:200) metode tersebut adalah:

\section{Metode Common Effect}

Pendekatan ini tidak memperhatikan dimensi individu atau waktu. Dalam estimasi common effect diasumsikan bahwa intersep dan slope (koefisien regresi) tetap untuk setiap perusahaan dan waktu.

\section{Metode Fixed Effect}

Metode ini mengasumsikan bahwa perusahaan memiliki intersep yang berbeda, tetapi memiliki slope regresi yang sama. Untuk membedakan antara perusahaan satu dengan yang lainnya digunakan variabel dummy (variabel contoh/semu) sehingga metode ini disebut Least Square Dummy Variables (LSDV).

\section{Metode Random Effect}

Model ini mengasumsikan bahwa setiap variabel mempunyai perbedaan intersep, tetapi intersep tersebut bersifat random atau stokastik.

Dari metode-metode di atas, akan dipilih satu metode yang paling tepat untuk analisis data panel. Langkah-langkah menentukan model dalam regresi dengan data panel adalah sebagai berikut:

\section{Uji Chow}

Uji Chow dilakukan untuk memilih model mana yang lebih baik, apakah common effect atau fixed effect. Bila $\mathrm{H}_{0}$ ditolak, lanjutkan dengan meregresikan data panel dengan metode random effect. Bandingkan model regresi mana yang akan digunakan dengan Uji Hausman.

\section{Uji Hausman}

Hausman mengembangkan suatu uji untuk memilih apakah menggunakan model fixed effect atau random effect yang lebih baik. ika $p$ value > 5\% maka kita menerima $\mathrm{H}_{0}$, yang artinya menggunakan model random effect, dan sebaliknya. Apabila hasil Uji Chow menunjukkan model common effect dan Uji Hausman menunjukkan random effect maka dilakukan uji yang ketiga yaitu Uji Lagrange Multiplier (Uji LM).

\section{Uji Lagrange Multiplier (Uji LM)}

Uji LM digunakan untuk mengetahui apakah model random effect lebih baik dari metode OLS atau common effect. Uji LM didasarkan pada nilai residual dari metode OLS. Jika nilai LM statistik lebih besar dari nilai kritis statistik chi-squares maka $\mathrm{H}_{0}$ ditolak, dan menggunakan model random effect.

\section{Uji Keberartian Regresi (Uji F)}

Uji F menguji signifikansi pengaruh seluruh variabel bebas terhadap variabel terikat sekaligus tanpa memperhatikan tingkat pengaruh dari setiap variabel secara terpisah. Hipotesis dalam penelitian ini:

$\mathrm{H}_{0}: \beta=0$, Manajemen persediaan dan manajemen piutang tidak berpengaruh negatif terhadap modal kerja perusahaan.

$\mathrm{H}_{1}: \beta \neq 0$, Manajemen persediaan dan manajemen piutang berpengaruh negatif terhadap modal kerja perusahaan.

\section{Uji Keberartian Koefisien Regresi (Uji t)}

Uji keberartian koefisien regresi (Uji t) menunjukkan pengaruh satu variabel independen secara individual terhadap variabel terikatnya dengan menganggap variabel 
independen lainnya bernilai tetap. Hipotesis dalam penelitian ini adalah:

- Untuk Manajemen Persediaan

$\mathrm{H}_{0}: \quad \beta_{1} \geq 0$, Manajemen persediaan berpengaruh negatif tidak signifikan terhadap modal kerja perusahaan.

$\mathrm{H}_{1}: \quad \beta_{1}<0$, Manajemen persediaan berpengaruh negatif signifikan terhadap modal kerja perusahaan.

- Untuk Manajemen Piutang

$\mathrm{H}_{0}: \quad \beta_{2} \geq 0, \quad$ Manajemen piutang berpengaruh negatif tidak signifikan terhadap modal kerja perusahaan.

$\mathrm{H}_{1}: \quad \beta_{2}<0$, Manajemen piutang berpengaruh negatif signifikan terhadap modal kerja perusahaan.

\section{Hasil Dan Pembahasan}

\section{Manajemen Persediaan}

Perputaran persediaan perusahaan manufaktur sektor industri barang konsumsi menunjukkan hasil yang berbeda-beda. Perbedaan tersebut bergantung pada kebijakan manajemen perusahaan dalam mengelola persediaannya. Semakin lama persediaan disimpan di gudang maka akan semakin lama dana terikat pada persediaan.

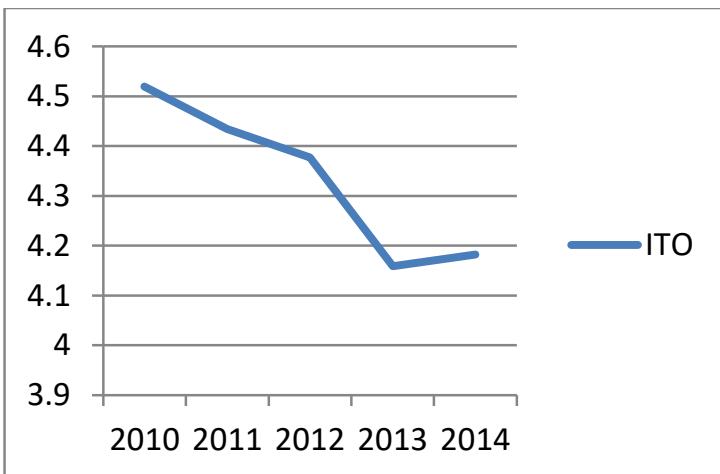

Sumber: Laporan Keuangan Perusahaan Tercatat di BEI (data diolah)

Gambar 1. Rata-rata Perputaran Persediaan Perusahaan Manufaktur Sektor Industri Barang Konsumsi yang terdaftar di BEI 2010 - 2014

Dari gambar di atas diketahui, rata-rata perputaran persediaan pada tahun 2010 adalah sebesar 4,52 kali, kemudian menurun pada 2011 menjadi 4,43 kali, pada 2012 sebesar 4,38 kali, hingga pada tahun 2013 sebesar 4,16 kali. Pada tahun 2014 rata-rata perputaran persediaan mengalami sedikit kenaikan 2\% menjadi 4,18 kali. Meskipun naik, rata-rata perputaran persediaan pada tahun 2014 masih lebih kecil dibanding dengan tahun 2010, 2011 dan 2012. Artinya, kenaikan rata-rata perputaran persediaan pada tahun 2014 belum optimal dan masih di bawah rata-rata secara keseluruhan yaitu 4,33 kali dan rata-rata industri 10,9 kali.

Manajemen persediaan yang baik akan mempertahankan tingkat perputaran persediaan yang efisien untuk mencegah terjadinya penumpukan di gudang. Namun dari hasil penelitian, hanya satu perusahaan yang mengalami peningkatan perputaran persediaan secara berturut-turut hingga tahun 2014, yaitu PT Sekar Laut Tbk. Sementara 16 perusahaan mengalami fluktuasi dan 3 perusahaan lainnya mengalami penurunan secara berturut-turut. Kenaikan perputaran persediaan menunjukkan keberhasilan manajemen dalam mengelola persediaannya. Dan sebaliknya, penurunan tingkat perputaran persediaan menunjukkan bahwa perputaran persediaan dalam perusahaan cenderung melambat dan periode penyimpanan persediaan di gudang semakin lama dari waktu ke waktu.

\section{Manajemen Piutang}

Sama halnya dengan perputaran persediaan, perputaran piutang perusahaan manufaktur sektor industri barang konsumsi juga menunjukkan hasil yang berbeda-beda. Namun, apabila dilihat dari rata-rata per tahun, dapat disimpulkan bahwa perputaran piutang perusahaan manufaktur sektor industri barang konsumsi mengalami penurunan dari tahun 2010 hingga tahun 2014.

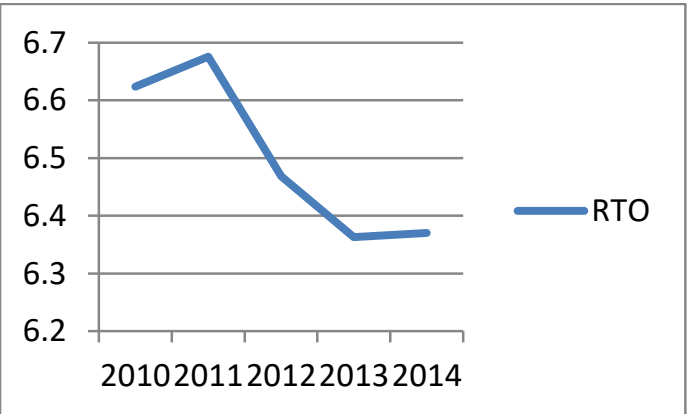

Sumber: Laporan Keuangan Perusahaan Tercatat di BEI (data diolah)

Gambar 2. Rata-rata Perputaran Piutang Perusahaan Manufaktur Sektor Industri Barang Konsumsi yang terdaftar di BEI 2010 - 2014 
Dapat dilihat dari gambar di atas rata-rata perputaran piutang pada tahun 2010 adalah sebesar 6,62 kali, lalu naik sebesar 0,06 menjadi 6,68 pada tahun 2011, namun turun kembali pada tahun 2012 menjadi 6,47 kali, 6,36 kali pada tahun 2013, dan 6,37 kali pada tahun 2014. Secara keseluruhan, perputaran piutang cenderung menurun sebesar 3,78\% dari tahun 2010 dengan rata-rata 6,50 kali, masih jauh di bawah rata-rata industri yaitu 10,1 kali.

Secara individual, tidak terdapat satu perusahaan pun yang mengalami kenaikan perputaran piutang secara berturut-turut dari tahun 2010 hingga tahun 2014. Sebaliknya, terdapat 3 perusahaan mengalami penurunan dan 17 perusahaan lainnya mengalami fluktuasi selama tahun 2010-2014. Perputaran piutang paling tinggi adalah 11,01 kali, yaitu perputaran piutang PT Indofood CBP Sukses Makmur Tbk. pada tahun 2014. Sedangkan perputaran piutang paling rendah adalah perputaran piutang PT Mustika Ratu Tbk. pada tahun 2013 yaitu 1,94 kali. Menurut Kasmir (2008:176) "Semakin tinggi rasio perputaran piutang menunjukkan bahwa modal kerja yang ditanamkan dalam piutang semakin rendah, sebaliknya jika rasio semakin rendah, ada over investment dalam piutang." Over investment ini akan merugikan perusahaan, karena dana tersebut sebenarnya dapat diinvestasikan pada hal yang lebih menguntungkan.

\section{Modal Kerja Perusahaan}

Rata-rata modal kerja perusahaan manufaktur sektor industri barang konsumsi dari tahun 2010 hingga 2014 mengalami kenaikan sebesar $64,12 \%$ dengan rata-rata satu triliun rupiah. Dari mulai 780 miliar pada 2010 hingga 1,2 triliun pada 2014.

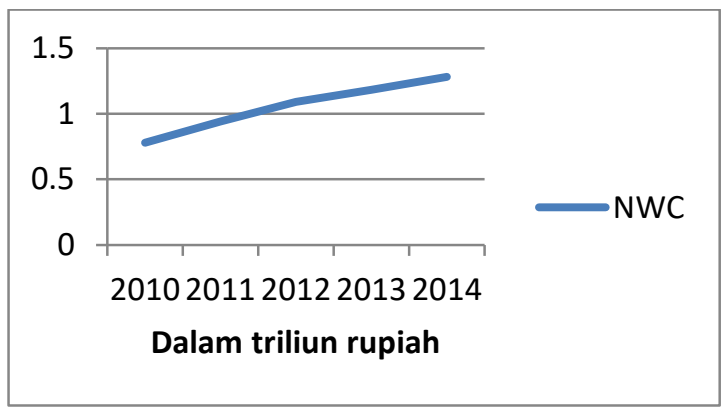

Sumber: Laporan Keuangan Perusahaan Tercatat di BEI (data diolah)
Gambar 3. Rata-rata Modal Kerja Perusahaan Manufaktur Sektor Industri Barang Konsumsi yang terdaftar di BEI 2010 - 2014

Dilihat dari modal kerja masing-masing perusahaan, hanya 6 perusahaan yang mengalami kenaikan modal kerja secara berturut-turut dan 14 perusahaan lainnya mengalami fluktuasi. Kenaikan modal kerja ini dapat diakibatkan dari peningkatan volume penjualan yang berdampak pada kenaikan persediaan dan piutang. Kenaikan persediaan dan piutang ini akan memperbesar aset lancar perusahaan, dan secara otomatis modal kerja perusahaan pun akan naik. Selain dari peningkatan volume penjualan, juga diakibatkan dari pelunasan kewajiban jangka pendek perusahaan.

Perusahaan yang memiliki modal kerja paling tinggi adalah PT Indofood CBP Sukses Makmur Tbk. dengan rata-rata 6 triliun rupiah. Sementara perusahaan dengan modal kerja terendah adalah PT Merck Sharp Dohme Pharma Tbk. pada tahun 2010 yaitu $-18,8$ miliar rupiah. Perusahaan lainnya yang memiliki modal kerja negatif adalah PT Siantar Top Tbk. pada tahun 2011 yaitu sebesar $-15,7$ miliar rupiah dan tahun 2012 sebesar -1,4 miliar rupiah. Modal kerja negatif memperlihatkan bahwa kewajiban lancar perusahaan lebih besar dibandingkan dengan aset lancarnya. Hal ini mengakibatkan perusahaan akan kesulitan membayar kewajibannya pada saat jatuh tempo. Modal kerja negatif juga dapat dikatakan bahwa sebagian aset tetap perusahaan dibiayai oleh kewajiban jangka pendeknya.

Perusahaan dengan modal kerja negatif menerapkan strategi modal kerja pendekatan agresif. Menurut pendekatan ini, proporsi utang jangka pendek lebih besar daripada utang jangka panjang. Sehingga sebagian kebutuhan jangka panjang akan dipenuhi dengan sumber dana jangka pendek. Perusahaan berani menanggung risiko yang cukup besar, sedangkan trade off yang diharapkan adalah memperoleh profitabilitas yang cukup besar.

Pengaruh Manajemen Persediaan dan Manajemen Piutang terhadap Modal kerja Perusahaan 
Penelitian ini digunakan data panel, yaitu gabungan antara data cross-section dan data time-series. Dari prosedur penelitian untuk data panel diperoleh hasil bahwa penelitian ini lebih baik menggunakan model Fixed Effect.

Dari pengujian hipotesis regresi data panel menggunakan model Fixed Effect dengan bantuan Eviews 8 diperoleh bahwa $F_{\text {hitung }}>$ $\mathrm{F}_{\text {tabel }}$ yaitu $98,21039>3,09$, sehingga $\mathrm{H}_{0}$ ditolak dan $\mathrm{H}_{1}$ diterima. Hal tersebut menunjukkan bahwa model regresi dalam penelitian ini berarti dan dapat digunakan untuk membuat kesimpulan secara simultan bahwa manajemen persediaan dan manajemen piutang berpengaruh negatif terhadap modal kerja perusahaan.

Model regresi yang berlaku adalah NWC $=$ 2,2130 - 0,2114 ITO - 0,0379 RTO. Di mana variabel ITO dan RTO memiliki pengaruh negatif terhadap NWC. Dengan Konstanta $\left(\beta_{0}\right)$ sebesar 2,2130, mengandung arti bahwa apabila manajemen persediaan $\left(\mathrm{X}_{1 i t}\right)$ dan manajemen piutang $\left(\mathrm{X}_{2 i t}\right)$ memiliki nilai 0 (nol), maka modal kerja perusahaan $\left(\mathrm{Y}_{i t}\right)$ akan bernilai 2,2130 (dalam triliun rupiah). Koefisien regresi sebesar -0,2114 memiliki arti bahwa setiap kenaikan ITO sebesar satu kali (dengan asumsi variabel lain konstan) maka akan mengurangi nilai NWC sebesar 0,2114 triliun rupiah. Koefisien regresi sebesar -0,0379 memiliki arti bahwa setiap kenaikan RTO sebesar satu kali (dengan asumsi variabel lain konstan) maka akan mengurangi nilai NWC sebesar 0,0379 triliun rupiah.

Secara simultan, kesimpulan pada penelitian ini sesuai dengan pendapat yang dikemukakan para ahli di antaranya adalah pendapat Syamsuddin (2007:280) yaitu "Semakin cepat perputaran persediaan berarti semakin kecil modal yang harus diinvestasikan dalam persediaan." Selain itu, Harjito dan Martono (2014:102) juga mengemukakan bahwa "Makin tinggi perputaran piutang berarti modal yang tertanam dalam investasi makin kecil, karena dana tertanam dalam piutang semakin cepat kembali sebagai kas masuk." Dari kedua pendapat tersebut, dapat disimpulkan bahwa manajemen persediaan dan manajemen piutang memiliki pengaruh berbanding terbalik dengan modal kerja perusahaan.

\section{Pengaruh Manajemen Persediaan terhadap Modal Kerja Perusahaan}

Uji parsial untuk manajemen persediaan $\left(\mathrm{X}_{1 i t}\right)$ diperoleh hasil bahwa pada taraf signifikansi 5\%, - $\mathrm{t}_{\text {hitung }}<-\mathrm{t}_{\text {tabel }}$ yaitu $-4,2074<-$ 1,98447, maka $\mathrm{H}_{0}$ ditolak. Artinya, pada tingkat kepercayaan 95\%, manajemen persediaan berpengaruh negatif signifikan sebesar 21,14\% terhadap modal kerja perusahaan. Adanya pengaruh yang signifikan ini mengindikasikan bahwa naik turunnya perputaran persediaan dapat menjelaskan atau memprediksi naik turunnya modal kerja. Sementara pengaruh negatif berarti bahwa nilai perputaran persediaan berbanding terbalik dengan nilai modal kerja perusahaan.

Persediaan merupakan salah satu bentuk investasi di mana terdapat dana yang ditanamkan di dalamnya. Semakin kecil atau semakin rendah tingkat perputaran persediaan berarti semakin lambat persediaan berputar dan periode persediaan di dalam gudang relatif lebih lama. Periode penyimpanan yang relatif lama akan menimbulkan penumpukan persediaan. Apabila persediaan terlalu besar, maka perusahaan menghadapi risiko seperti memperbesar biaya pemeliharaan dan penyimpanan di gudang serta memperbesar kemungkinan kerugian akibat kerusakan dan penurunan kualitas barang yang akan memperkecil keuntungan yang diperoleh perusahaan. Biaya-biaya yang dikeluarkan tersebut akan sangat mempengaruhi kebutuhan modal kerja perusahaan. Maka, semakin rendah perputaran persediaan akan mengakibatkan tingginya modal kerja perusahaan.

Manajemen persediaan yang baik memiliki perputaran persediaan yang relatif tinggi dalam arti perputaran yang tinggi mengindikasikan kelancaran perputaran persediaan. Sehingga tingginya perputaran persediaan dapat memperkecil kebutuhan modal kerja perusahaan. Maka dapat pula disimpulkan bahwa semakin baik manajemen persediaan suatu perusahaan, maka akan memperkecil kebutuhan modal kerja perusahaan sampai pada tingkat tertentu.

\section{Pengaruh Manajemen Piutang terhadap Modal Kerja Perusahaan}

\author{
Berbeda dengan hasil yang ditunjukkan \\ manajemen persediaan, hasil pengujian
}


hipotesis untuk manajemen piutang $\left(\mathrm{X}_{2 i t}\right)$, pada taraf signifikansi $5 \%$, $-\mathrm{t}_{\text {hitung }}>-\mathrm{t}_{\text {tabel }}$ yaitu $0,8089>-1,98447$, maka $\mathrm{H}_{0}$ diterima. Artinya, pada tingkat kepercayaan $95 \%$ manajemen piutang berpengaruh negatif tidak signifikan terhadap modal kerja karena presentasenya hanya $3,79 \%$ dan masih di bawah $5 \%$. Tidak adanya pengaruh yang signifikan ini mengindikasikan bahwa naik turunnya perputaran piutang tidak dapat menjelaskan atau memprediksi naik turunnya modal kerja.

Manajemen piutang yang baik memiliki perputaran piutang yang relatif tinggi dalam arti periode penagihan piutang perusahaan relatif lancar dan cepat. Sehingga tingginya perputaran piutang dapat memperkecil kebutuhan modal kerja perusahaan. Maka dapat pula disimpulkan bahwa semakin baik manajemen piutang suatu perusahaan, maka akan memperkecil kebutuhan modal kerja perusahaan sampai pada tingkat tertentu.

Namun meskipun pada hasil uji F diketahui bahwa manajemen piutang memiliki pengaruh negatif terhadap modal kerja perusahaan. Tetapi pada hasil uji t menunjukkan bahwa ternyata pengaruhnya hanya sebesar 3,79\% saja, yang mana dapat disimpulkan bahwa pengaruh negatif manajemen piutang terhadap modal kerja tersebut tidak signifikan. Hal ini terjadi karena piutang perusahaan adalah akibat dari penjualan kredit perusahaan. Sementara, selain penjualan secara kredit, perusahaan juga menjual produknya secara tunai. Penjualan tunai ini akan mempercepat aliran kas masuk karena tidak melewati pos piutang. Siklus kas masuk yang lebih cepat atau relatif lancar membuat perusahaan tidak memerlukan pinjaman jangka pendek dalam jumlah yang besar. Pengurangan jumlah pendanaan jangka pendek ini akan menambah modal kerja perusahaan. Maka, dalam hal ini, peningkatan perputaran piutang tidak membuat modal kerja perusahaan menurun atau dapat dikatakan bahwa tingkat perputaran piutang tidak mempengaruhi tingkat modal kerja perusahaan.

Selain itu, seperti yang telah dijelaskan sebelumnya bahwa rata-rata perputaran piutang perusahaan manufaktur sektor undustri barang konsumsi adalah 6,50 kali. Nilai ini masih jauh lebih kecil dibandingkan dengan rata-rata industri yaitu 10,1 kali. Perputaran piutang yang lambat ini menjadi salah satu penyebab pengaruh manajemen piutang terhadap modal kerja perusahaan tidak signifikan.

Hasil penelitian ini membantah teori sebelumnya mengenai modal kerja perusahaan. Di mana dikatakan bahwa tingkat modal kerja perusahaan dapat dipengaruhi oleh tingkat perputaran piutangnya atau manajemen piutangnya. Penelitian ini juga membantah penelitian sebelumnya mengenai modal kerja perusahaan di antaranya adalah penelitian oleh Rao dan Gaglani (2014) dan penelitian Ramana, dkk (2013) yang menerangkan bahwa manajemen piutang mempunyai pengaruh yang signifikan terhadap modal kerja.

\section{Kesimpulan}

\section{Simpulan}

Kesimpulan dari penelitian ini adalah sebagai (1) Manajemen persediaan yang diukur menggunakan perputaran persediaan pada perusahaan manufaktur sektor industri barang konsumsi yang terdaftar di BEI cenderung menurun dengan rata-rata 4,33 kali. Manajemen piutang yang diukur menggunakan perputaran piutang cenderung menurun dengan rata-rata 6,50 kali. Sementara, Modal kerja perusahaan yang diukur menggunakan net working capital cenderung naik dengan ratarata satu triliun rupiah. (2) Manajemen persediaan berpengaruh negatif signifikan terhadap modal kerja perusahaan manufaktur sektor industri barang konsumsi yang terdaftar di BEI (3) Manajemen piutang berpengaruh negatif tidak signifikan terhadap modal kerja perusahaan manufaktur sektor industri barang konsumsi yang terdaftar di BEI (4) Manajemen persediaan dan manajemen piutang secara simultan berpengaruh negatif signifikan terhadap modal kerja perusahaan manufaktur sektor industri barang konsumsi yang terdaftar di BEI.

\section{Saran}

Berdasarkan hasil penelitian dan kesimpulan yang telah diuraikan sebelumnya, terdapat keterbatasan dalam penelitian ini di antaranya adalah dalam hal pemilihan indikator modal kerja yang menggunakan satuan rupiah sehingga terdapat perbedaan dengan variabel independennya yang menggunakan rasio. Kemudian dalam pemilihan objek penelitian, 
rentang waktu yang diteliti dan metode yang digunakan dalam penelitian.

Adapun saran yang dapat peneliti berikan antara lain (1) Perusahaan harus memberikan perhatian pada manajemen persediaan terkait tingkat persediaan dalam perusahaan, periode persediaan di dalam gudang, hingga masalah pemesanan dan penjualan. (2) Perusahaan harus dapat mengelola piutangnya dengan kebijakan-kebijakan kredit seperti penetapan jangka waktu kredit, potongan/diskon yang diberikan, analisis kredit terhadap pelanggan dan tata cara penagihan. (3) Dengan manajemen persediaan dan manajemen piutang yang baik diharapkan perusahaan juga dapat mengelola kebijakan modal kerjanya dengan baik. (4) Untuk peneliti selanjutnya yang tertarik dalam meneliti manajemen modal kerja dan unsur-unsur di dalamnya seperti manajemen persediaan dan manajemen piutang, disarankan lebih ketat dalam pemilihan objek penelitian, dan mencoba sektor baru yang belum pernah diteliti. Ada baiknya menggunakan data observasi yang lebih besar lagi. Kemudian pemilihan indikator penelitian juga sangat penting dan berpengaruh terhadap hasil penelitian. Dan indikator berupa rasio cenderung lebih mudah diolah daripada data dalam satuan rupiah.

\section{Daftar Pustaka}

Andari, R. (2009). Manajemen Keuangan Suatu Pengantar. Bandung: UPI Press.

Brigham, \& Houston. (2011). Dasar-dasar Manajemen Keuangan-Essentials of Financial Management. Jakarta: Salemba Empat.

Harjito, A., \& Martono. (2014). Manajemen Keuangan Edisi Ke-2. Yogyakarta: Ekonisia.

Irawati, S. (2006). Manajemen Keuangan. Bandung: Pustaka.

Margaretha, F. (2011). Manajemen Keuangan untuk Mengajar Nonkeuangan. Jakarta: Erlangga.

Ramana. (2013). Impact of Receivables Management on Working Capital and Profitability : A Study on Select
Cement Companies in India. International Jornal of Marketing, 163-171.

Rao, Smita, Gaglani, \& Hetal. (2014). Impact of Receivable Management on Working Capital : A Study on Select Cement Companies . International Journal of Management Research \& Review, 651-659.

Sudana, I. M. (2011). Manajemen Keuangan Perusahaan Teori dan Praktik. Jakarta: Erlangga.

Sutrisno. (2012). Manajemen Keuangan Teori, Konsep \& Aplikasi. Yogyakarta: Ekonisia.

Yamin, S. (2011). Manajemen Keuangan Perusahaan; Konsep Aplikasi dalam Perencanaan, Pengawasan dan Pengambilan Keputusan. Jakarta: Salemba Empat 